\title{
Where Do Schools in Jordan Stand on Visual Management? And What Is the Effect of This on Students' Acquisition of Lifelong Learning Skills?
}

\author{
Dalal Mohamad Al-Zoubi \\ Professor of Educational Administration, Education Science Department, Al-Balqa Applied University, Irbid, Jordan \\ Email: dalal.zoubi@bau.edu.jo,dalalzoubi@yahoo.com
}

How to cite this paper: Al-Zoubi, D. M. (2020). Where Do Schools in Jordan Stand on Visual Management? And What Is the Effect of This on Students' Acquisition of Lifelong Learning Skills? Open Journal of Leadership, 9, 113-139.

https://doi.org/10.4236/oj1.2020.92008

Received: March 11, 2020

Accepted: June 5, 2020

Published: June 8, 2020

Copyright ( 2020 by author(s) and Scientific Research Publishing Inc. This work is licensed under the Creative Commons Attribution International License (CC BY 4.0).

http://creativecommons.org/licenses/by/4.0/

\begin{abstract}
The main purpose of this study is to explore to what extent the principals of Jordanian public schools are practicing the functions of VM and what impact this practice has on students' acquisition of the LLS. A cluster random sample was derived from the study population (public schools in Jordan). And the survey strategy was used to carry out this study in 26 Jordanian public schools by using two questionnaires. The first one was directed to the teachers and measured the principals' practices of the functions of the VM, and the second one was directed to the students and measured the students' acquisition of the LLS. The results of the study are expected to contribute to a better understanding of the two variables addressed in this study. And to benefit from these results in the way those principals can manage their schools in the future.
\end{abstract}

\section{Keywords}

Visual Management, Lifelong Learning Skills, School, School Principal, Students

\section{Introduction}

The focus on the future of education is a very important subject in today's world. There is an ongoing call by those involved in education to ensure that education in the twenty-first century is comprehensive, accessible to all and qualitative, whether in management, curricula, personnel or technology, which expands and maintains the quality of education. 
This depends on the nature of the school administration and its interests. Is the school managed with a vision of the future and challenges and the seriousness of the school's message to society? Or is it managed by a short-term perspective that makes the educational process a burden on development (Al-Abady, 2007)?

"From our experience in the school's education sector, the school administration is the most important component which leads the school to achieve successful outputs", Liff and Posey (2004) said. The most important element of it is the students' acquisition of lifelong learning skills (LLS), which enable them to face life after graduation, whether in the university or in the labor market or the society in general (Thürer, Stevenson, Silva, Land, Fredendall, \& Melnyk, 2014).

To achieve this, the school administration must use modern management concepts, the most prominent of which are the concepts of visual management (VM).

VM has become a trend over the last few years. Now it becomes an important management tool. The target of it is to harmonize communication. For example, VM provides solutions for various issues such as rapid detection of abnormal situation, continuous maintenance of a safe environment, prevention of operational error and knowledge exchange (Koichi \& Hiroshi, 2016). With rapid globalization in the future, the education system will become more complex than it is today, and VM systems will gain further significance. The use of VM in educational institutions contributes to the development of performance and improves the performance of individuals to facilitate the achievement of the educational goals of the educational institution. It also contributes to improving the management of the institution, thus improving the quality of education and overcoming the state of anxiety and tension towards the future of the institution and its graduates (Al-Hudhali, 2015).

The problem of this study stems from the fact that in spite of the increasing interest in school education and its outputs in Jordan, many important issues have not received sufficient attention in research; these include such modern management concepts as VM, as well as research into the mission of the school in preparing students to face life after graduation by providing them with the necessary skills.

While the researcher was reviewing foreign and Arab sources on the subjects of VM and the skills for lifelong learning, she found no studies that considered the two subjects together, but most studies, and there are few of them in the field of education, studying each subject in isolation from each other. She also found that most foreign studies on VM were conducted in the business sector, especially industry.

So, in light of the lack of studies in the field of education and the absence of any Jordanian or Arab study within the scope of the researcher's knowledge that linked the VM in schools and the acquisition of LLS by students, the researcher was encouraged to study this problem because she believes that the study will 
make important findings as the subject itself is important. Thus, the problem can be summed up with the following main question:

"To what extent are the principals of Jordanian public schools practicing the functions of VM and what is the effect of this practice on students' acquisition of the LLS?".

\section{Background}

\subsection{Visual Management (VM)}

VM is a well-known management technique and one of the main reasons for the success of the Japanese experience. The administration in Japan is called Gemba Kaizan (Imai, 2018), which means to manage the problem from a place where time can be managed with the right precision and speed to get rid of the roots of this problem and prevent its recurrence in the future. In this way, the elements of management are completed: planning, implementation, follow-up and development. For the integration of these elements to give a useful result, three basic strategies must be adhered to: establishing rules of action, purging corruption, and rationalizing (Kurdi, n.d).

The principal is a key pillar of improving the learning process and an important factor in achieving the goals of education and improving outputs. In the light of the challenges and changes in societies, as well as the methods and requirements of school management, the responsibilities and functions of the school principal have increased (Witt, Kacmar, Carlson, \& Zivnuska, 2002). So, the educational and global trend towards having an educational leader who can lead the school with high efficiency became necessary (National Center for Assessment in Higher Education, n.d.).

Moreover, it becomes tough for an educational leader to perform his operation effectively when employees are unaware of what is happening all around. It is highly significant to communicate information throughout all levels as well as departments of educational institutions. For teams, there is always a need to know about the main targets and goals which they will pursue in future. Keeping track of how work is being done is highly crucial for an educational leader and that is what VM management does in schools. Through VM, information is communicated clearly, widely and quickly.

Jordan is known as a new or young society since $37.3 \%$ of its population is under fifteen years old (Ministry of Education, 2007). It is indicated by the Jordanian population's qualitative structure that the number of female students is less than male students, according to a report in 2005. Jordan, after receiving 2 million refugees from Iraq and Syria, has turned out to be a burdened state, as it has minimal capacity. While making a comparison of Jordan with other underdeveloped countries, particularly non-oil-producing countries, an outstanding place is occupied by Jordan in the criteria of human development even though it has limited gross national product (GNP) and natural resources. In all these crises, the need for VM cannot be ignored in the field of education to keep up 
with the modern world and management advances. While keeping in view the competitive environment, the Jordanian educational management needs to adopt new ways to achieve progress and development. Identifying the Jordanian management's attitude towards the integration of VM in their school is also important (Ministry of Education, 2007). There is a need to make VM a part of Jordanian educational management system because it would help workers, not just supervisors and management, have easy access to all the knowledge and information they want. VM can be considered the process control's basic element, which ultimately leads to continuous improvement (Albirini, 2006).

Innovation and development in administrative organizations have become the main concern for administrators and experts. Traditional management is no longer suitable for keeping pace with the new knowledge society. It is necessary to provide new management that works according to new concepts and methods through which the objectives are achieved (Tjell \& Bosch-Sijtsema, 2015). It is a VM technique that contributes to the value and effectiveness of the realism and transparency of vertical and horizontal relations within the pillars of institutional work, which is based on the management of the problem from its place accurately and quickly to get rid of the roots of the problem and work to reduce the recurrence in the future, in addition to time management at the same time (Tezel, Koskela, \& Tzortzopoulos, 2009; Al-Hudhali, 2015).

The most important principles of VM are participation in decision-making. The more the problem is visually identified, the more people see it and the more interest in the problem there is (Waeyenbergh \& Pintelon, 2009). The integration of the principles of $\mathrm{VM}$ is through the information that is available to the senior departments to enhance the effectiveness of the decision-making process, which is based on the actual facts obtained from different parties in the institution. This will provide an important information base that the institution can refer to when necessary in making important decisions (Al-Hudhali, 2015).

The objectives of the VM are summarized as follows:

1) Providing quality service.

2) Knowing the views and expectations of the beneficiaries and measuring their level of satisfaction with the services provided to them.

3) Developing and improving channels of communication between the beneficiary and the providers.

4) Enabling institutions to perform their functions efficiently and effectively.

5) Achieving better performance levels.

6) Satisfying the beneficiaries.

7) Improving the morale of the employees can enhance their confidence and ensure the best results and level of performance (Al-Hudhali, 2015).

The academics and practitioners knew that there was a need for a modern administrative system to move towards more open management practices that are fit for the future. They suggest the "democracy of information", which is a basic element in VM, where employees can feel more engaged in their organiza- 
tion (Bititci, Cocca, \& Ates, 2016).

\section{The Functions of Visual Management}

A literature review was identifying functions of $\mathrm{VM}$ as follows:

1) Transparency: Transparency refers to honesty and openness without hiding, lying, or misleading. It also means the method of work that creates an environment in which information about current circumstances, decisions and actions is available, perceived and understood. The leader must be transparent, avoid disturbing the mix with his suspicions, and be completely away from anything that affects his secretariat and undermines his dignity of material and moral behaviors; he should be transparent in all the information and decisions he provides to clients, employees or competitors.

Transparency can be achieved through openness and honesty, the institution's policy declaration, the periodic announcement of the organization's decisions, accuracy and openness, confidentiality of personal information, and the adoption of written and publicized procedures that protect the human resources of the organization (Administrative Transparency and How to Achieve It, 2017).

2) Discipline: Discipline at work is the secret of the progress of peoples and the success of institutions, and the most important manifestations of civilization and professional ethics. The commitment to discipline must stem from the individual without external influences of her sense of responsibility towards her work, but the practical reality proved that the system of the institution and the way the owner works with employees greatly determines the discipline of employees within an organization.

Discipline at work encompasses the entire business cycle of job performance and investment of employee energies to benefit in achieving the highest rate of production of the institution as well as adherence to the standards and policies of the institution to reach its objectives.

Management can help employees become accustomed to discipline at work by motivating them, notifying them that the institution belongs to all its members, following a clear strategy, setting good leadership example, staying away from useless rules, not using punishment as the first solution, organizing recreational activities for employees, and giving workers a degree of freedom (Hasan, 2017).

3) Continuous improvement in work depends on such factors as continuous training and development, tackling mistakes and focusing on solving them, building trust among employees, work as a team to succeed, supporting strengths, analyzing and addressing all existing problems by setting a schedule and a daily meeting to reduce existing mistakes and finding appropriate solutions, having clear policies and procedures in place, setting goals and working to achieve them, and developing a clear vision (Tezel, Koskela, \& Tzortzopoulos, 2009).

4) Job facilitation: This is a process for motivating groups of people to solve any problem. Good facilitators know how to do it, establish a clear objective, create opportunities for discussion, and lead groups toward constructive solu- 
tions. A facilitator does not need a specific job title or a certain amount of experience to become effective-he just needs to develop skills that give structure and purpose to the otherwise unruly art of collaboration (Klein, 2017).

5) On-the-job training: There are four main directions to focus on the success of the training process (In-Service Training, 2014):

- The need to meet the challenges of change: This trend focuses on the principles of responding to changes in the design of training programs, refusal to adopt rigid designs, and selection of alternatives to ensure the provision of training programs that allow adaptation to changes that occur at the level of function or task.

- Establishing high-performance work environments: This trend is based on the assumption that methods of upgrading human performance should begin by examining the strengths and weaknesses of work environments, not individual deficiencies or efficiency.

- Organizing work activities in creative ways: this trend is based on the formation of creative teams and training them to operate independently so that each can perform the functions of others if necessary.

- Upgrading the efficiency of the employees: this trend focuses on facilitating planned learning rather than guiding it and pushing workers to cope with changes in their careers and professions and to adapt to these changes through follow-up and learning to acquire knowledge, experience, and skills.

6) Creating shared ownership: Certain steps can be taken to ensure that employees have a personal stake in team-wide endeavors (Napolitano, 2017):

- Value your employees: Be sure that each team member feels valued. Managers can do this by creating a group understanding of respect.

- Set clear goals-and do not micromanage their execution: Managers are responsible for delivering the cohesive results of a team effort.

- Talk and listen: Create a sense of honesty and trust in your team by being transparent with employees about projects and the institution's direction. Listen to and value employees' feedback.

7) Open up decisions and communication: Open communication is vital during decision-making processes. So, managers should listen to their employees' feedback.

8) Management by facts: Fact-based management involves the use of facts and data based on statistics. Openness or willingness to share ideas and information willingly, openly and accurately is a condition for gaining the confidence of employees in management. Pure reality helps managers overcome the negative side of regulatory policy associated with the abuse of power and secrecy, which is seen as a barrier to democracy by many.

VM helps to eliminate information monopolies in different layers and encourages people to face their own performance facts. Employees who lack other forms of authority and control can use information and knowledge as a form of control and defense mechanism (Tezel, Koskela, \& Tzortzopoulos, 2009). 
9) Simplification and Unification (Witt, Kacmar, Carlson, \& Zivnuska, 2002; Tezel, Koskela, \& Tzortzopoulos, 2009):

- Information management in dynamic and complex environments sometimes goes beyond the efforts and capabilities of individuals. Lack of information or information flow may simply lead to poor performance, conflicts, misunderstandings, disagreements, etc. Strategic information needs to be simplified, especially in decision-making processes.

- VM monitors, filters, simplifies, and effectively delivers quality information, which is essential, and in this way, an information field is created, through which employees can pull information whenever they feel the need.

- Organizations are made up of interconnected social and technical departments, with different layers. One of the administrative issues is to achieve a common understanding among these layers. People may erroneously think they are working in isolation but the truth is often otherwise. The boundaries between layers, the boundaries between functional units, the boundaries between the Organization and the outside world and the boundaries between organizational units located in different geographical areas can be partially diminished with the exchange of information and the creation of dialogue.

Therefore, VM acts as a standard that helps to clear the harmful effects of fragmentation.

\subsection{Lifelong Learning}

The school principal is a key pillar of improving the learning process and an important factor in achieving the goals of education and improving their outputs. In light of the challenges and changes in societies, as well as the methods and requirements of school management, the responsibilities and functions of the school principal have increased. So, the educational and global trend towards having an educational leader who can lead the school with high efficiency became necessary (National Center for Assessment in Higher Education, n.d.). Since the most important outcome of the school is preparing students for life by focusing on their lifelong learning, there is a need to use a modern management system such as VM to achieve this.

Over the last 20 years, lifelong learning has become a key theme in various nations, including the European region, the UK, and globally. The increasing interest in lifelong learning has come from the growing need for high levels of numeracy, literacy, and emotional stability in the face of transformation, challenge and cognitive adaptation in a rapidly changing world (Clark, 2015).

Education today must prepare citizens for the future. By focusing on the need for cooperation in the global economy, students can integrate better in the world of work. Workers must be willing to update constantly and re-educate themselves to acquire new learning.

Lifelong learning must be the goal of every teacher and student, and curricula during educational experiments should pave the way for the study of this goal 
(Bonds, 2003; Hosseini, 2006).

LLS are particularly important in the knowledge society, as they provide more opportunities in the labor market and are easier to adapt to continuous change. Capacity development increases the independence and motivation of students and makes their learning more attractive. Every citizen must develop skills and knowledge, actively participate in social life and succeed in the labor market (Weiler, 2018). The most important basis for learning is language, literacy, numeracy, and ICT skills, while learning to learn helps in all activities of education. Every citizen, especially teachers involved in adult education, skills, and knowledge must constantly improve, actively participate in social life and work successfully in a changing job market and business world (Gedviliené, Teresevičienè, Zydžiūnaitè, \& Kaminskienè, 2012; Al-Tarawneh \& Altweiss, 2018).

\section{Lifelong Learning Skills (LLS)}

Classifications of learning skills vary according to the classification axes. If we consider lifelong learning as a process, we find skills related to planning this learning and independent study, skills related to the procedures of implementing learning and organizing the process of acquiring knowledge, and other skills related to self-evaluation. In the light of human characteristics in the knowledge society, a set of skills is formed in terms of the ability to criticize, analyze, innovate, interpret, accept change, contribute to the production of new knowledge, communicate, accept the other's opinion, as well as the appetite for lifelong learning (Alfalit, 2015).

Khalil (2005) adds some features that he considers to be among the skills of human learning to facing life, most notably the following:

- Critical thinking and the ability to make judgments: It includes the expression of opinion, sentencing, decision-making, and the ability to criticize ideas and reach what can be implemented from these ideas.

- Meaningful culture: It includes the implantation of multiple forms of culture and the analysis of the meanings of any symbols and cultural forms.

- Cooperation, teamwork, and community service: In association with cultural centers and community institutions.

- Ability to adapt, change and acquire new skills.

Some researchers categorize learning skills in the light of the organization of the learning process, which includes the skills of organizing study and schedules and how to organize time, and effective reading skills related to improving the level of understanding and comprehension, concentration, and writing skills related to summarizing, taking notes, writing reports, articles, and skills with access to learning resources associated with the use of the library, the use of tools and techniques, skills related to assessment, methods of review, self-assessment, research and organizational skills, skills of gainful interaction and fruitful communication (Ghabayin, 2001). 
It is clear from the above that the individual acquires LLS on his own in accordance with his speed and abilities, that this learning responds to changes and rapid developments in the various areas of knowledge, and that it is not only a cognitive activity or behavioral pattern but a personal trend. Thus, the current study has benefited from the previous skills and classifications in line with its objectives and the nature of the sample, so the LLS are defined as follows:

1) Basic skills (cognitive, methodological, technological and linguistic) such as acquisition of basic and professional knowledge, decision-making, using information to solve problems, using the Internet and email, skills in essay writing and explaining ideas, having skills in effective listening and clear speaking, communication in the mother tongue and in foreign languages, managing time and meetings and planning tasks.

2) Personal and social skills such as self-critical abilities, ability to work in teams, interpersonal (interaction) skills, acceptance of cultural diversity and multiculturalism, ability to work in international environments, ethical commitment, coping with stress, receiving feedback positively, taking responsibility for own learning, evaluating strengths and weaknesses at work.

3) Organizational skills such as ability to apply knowledge in practice, research skills, ability to adapt in new situations, ability to generate new ideas (creativity), the understanding of other cultures and customs, ability to work, self-learning, initiative and entrepreneurial spirit, concern about quality, monitoring and correcting performance, exercising leadership, negotiating to arrive at a decision, working with others of culturally diverse backgrounds, knowing how to learn, reasoning.

Based on the situation on the ground, this study decided to work with students' acquisition of the LLS since it is expected that school principals' practice of VM functions will affect student acquisition of LLS.

\section{The Importance of the Study}

A considerable body of research deals with the terms "VM" and students "LLS" skills, but no study has simultaneously examined the associations among these variables in the different institutions, especially schools. This paper will, therefore, examine each of the variables and dimensions to provide, on the one hand, operational clarity, and on the other hand, theoretical and empirical evidence for the association of these variables.

Thus, the importance of this study is that it addresses one of the issues affecting the essence of the educational institutions in general, which is the LLS of the students at Jordanian public schools, and whether it is affected by the practice of the functions of VM by school principals. There is currently no study nationally or internationally that finds an association between the school principal practicing the function of VM on the one hand and the LLS of the school's students on the other.

The results of this study might reveal real information that helps school prin- 
cipals to understand the reality of their practice of the function of VM and the reality of the students' LLS. And it could help decision-makers like the Ministry of Education find ways to enhance students' LLS and the practice of the functions of VM by the school principals. In addition, there is a possibility of benefitting from the results of this study at other educational institutions like private schools inside and outside of Jordan as an indication of the importance of LLS, which is expected to affect the future of the students and the various institutions of society.

\section{The Purposes of the Study}

The main purpose of this study is to explore to what extent the principals of Jordanian public schools are practicing the functions of VM and the effect of this practice on students' acquisition of the LLS.

Through the main purpose of the study, the following sub-goals will be achieved:

1) The extent to which Jordanian public school principals practice the functions of VM.

2) The extent to which the students of Jordanian public schools acquired the LLS.

3) The differences in practicing the functions of VM by Jordanian public school principals according to education directorate, school gender, qualification, and years of experience of the teacher sample.

4) The differences in the acquisition of LLS by Jordanian public school students according to education directorate, school gender, and the secondary education branch of the student sample.

5) The effect of practicing the functions of VM by Jordanian public school principals' on the student's acquisition of the LLS.

\section{Research Design and Methodology}

In this section, the researcher will discuss the study methodology, populations and samples. The study's questions and hypotheses will be determined, in addition to its variables. The tools used to collect data will be explained, as well as the statistical methods that have been adopted to analyze the data and extract the results.

\subsection{Research Questions \& Hypotheses}

Two questions and three hypotheses are derived from the main study query:

Q1: To what extent do the principals of Jordanian public schools practice the functions of VM from the teacher's point of view?

Q2: To what extent do the students of Jordanian public schools acquire LLS from their point of view?

$\mathrm{H1}$ : There are statistically significant differences in practicing the functions of VM by Jordanian public school principals according to education directorate, 
school gender, qualification, and years of experience of the teacher sample.

H2: There are statistically significant differences in the acquisition of LLS by Jordanian public school students according to education directorate, school gender, and the secondary education branch of the student sample.

H3: There is a statistically significant effect of practicing the functions of VM by Jordanian public school principals on the student's acquisition of LLS.

\subsection{Assessment of Variables}

Two questionnaires will be used to assess the variables of the study as follows. "The first one will be directed to the teachers to assess the independent variable, while the second one will be directed to the students" to assess the dependent variable.

1) The independent variable: The principals' practice of the functions of VM.

2) The dependent variable: The students' acquisition of the LLS.

3) Moderating variables:

a) Education directorate: (Beny Kenana, Beny Obaid, Jordan Valley).

b) School gender: (male, female).

c) Qualifications of the teachers: (bachelor or less, higher than bachelor).

d) Years of experience for teachers: (10 years or less, more than 10 years).

e) The secondary education branch for students: (academic branch, vocational branch).

\subsection{Samples and Data Collection}

This is a causal study, and to achieve its objectives, the survey strategy was used to carry it out in 26 public schools in Jordan.

A cluster random sample was derived from the study population (public schools in Jordan) by selecting one of the three main education directorates in the first stage (Northern Jordan, Central Jordan, Southern Jordan). In the second stage, three sub-directorates of education were chosen from the main education directorates selected in the first stage. In the third stage, 26 secondary schools were selected from the three sub-directorates. In the fourth stage, 217 teachers were selected in these schools to answer the questions of the first questionnaire. Finally, in the fifth stage, 1085 students were selected from the twelfth grade in these schools to answer the questions of the second questionnaire (see Table 1).

The criterion in light of which the study sample of teachers was selected is that any initiatives or decisions concerning the functions of VM have to be taken at the principal level. Teachers working in the middle level in the school structure are the linking chain between the principal and the students, and they are concerned with the publication of ideas and decisions of the school principal and circulating them to the students and those related to the school. In addition, they are involved with the principal in many of the school management issues; therefore, they are expected to have good information about the principal practicing the functions of VM. 
Table 1. Study populations and samples (Cluster random sample).

\section{The Ministry of Education/Education Directorates}

\begin{tabular}{|c|c|c|c|c|}
\hline \multicolumn{2}{|c|}{$\begin{array}{l}\text { North Education Directorates } \\
\text { (Main group) }\end{array}$} & $\begin{array}{l}\text { Centre Education Directorates } \\
\text { (Main group) }\end{array}$ & \multicolumn{2}{|c|}{$\begin{array}{l}\text { South Education Directorates } \\
\text { (Main group) }\end{array}$} \\
\hline First selection: & \multicolumn{4}{|c|}{ (Main group) North directorates } \\
\hline Mafraq Kasaba & Beny Kenana & Tayba \& Westeya & $\begin{array}{l}\text { Northern Badia } \\
\text { Western }\end{array}$ & Relief Agency \\
\hline Ajloun & Irbid Kasaba & Ramtha & $\begin{array}{l}\text { Northern Badia } \\
\text { Eastern }\end{array}$ & Mazar \\
\hline Jerash & Beny Obaid & Koura & $\begin{array}{l}\text { Northern Jordan } \\
\text { Valley }\end{array}$ & \\
\hline $\begin{array}{l}\text { Second } \\
\text { selection: }\end{array}$ & $\begin{array}{l}\text { (Sub-group) } \\
\text { Directorate of Beny } \\
\text { Kenana } \\
\text { (No. of Secondary } \\
\text { schools: } 27 \text { ) }\end{array}$ & $\begin{array}{l}\text { (Sub-group) } \\
\text { Directorate of } \\
\text { Beny Obaid } \\
\text { (No. of secondary } \\
\text { schools } 15)\end{array}$ & $\begin{array}{l}\text { (Sub-group) } \\
\text { Directorate of } \\
\text { Northern Jordan } \\
\text { Valley } \\
\text { (No. of secondary } \\
\text { schools } 10)\end{array}$ & \\
\hline Third selection: & $\begin{array}{l}\text { Sample of secondary } \\
\text { schools: } 14 \text { schools }\end{array}$ & $\begin{array}{l}\text { Sample of secondary } \\
\text { schools: } \\
7 \text { schools }\end{array}$ & $\begin{array}{l}\text { Sample of } \\
\text { secondary schools } \\
5 \text { schools }\end{array}$ & \\
\hline \multicolumn{4}{|c|}{ Fourth selection: The teacher population and sample of the selected schools } & Total No. \\
\hline Population & 248 & 149 & 148 & 545 \\
\hline Sample & 99 & 59 & 59 & 217 \\
\hline \multicolumn{5}{|l|}{ School gender. } \\
\hline Male & 46 & 26 & 24 & 96 \\
\hline Female & 53 & 33 & 35 & 121 \\
\hline \multicolumn{5}{|l|}{ Year of experience: } \\
\hline 10 or less & 40 & 25 & 32 & 97 \\
\hline More than 10 & 59 & 34 & 27 & 120 \\
\hline \multicolumn{5}{|l|}{ Qualification: } \\
\hline Bachelor or less & 87 & 49 & 50 & 186 \\
\hline $\begin{array}{l}\text { Higher than } \\
\text { Bachelor }\end{array}$ & 12 & 10 & 9 & 31 \\
\hline Fifth selection: & \multicolumn{4}{|c|}{ The students population and sample of the selected schools } \\
\hline Population & 900 & 602 & 570 & 2072 \\
\hline Sample & 495 & 295 & 295 & 1085 \\
\hline \multicolumn{5}{|l|}{ School gender. } \\
\hline Male & 297 & 133 & 119 & 549 \\
\hline Female & 198 & 162 & 176 & 536 \\
\hline \multicolumn{5}{|l|}{ Education branch: } \\
\hline Academic & 385 & 245 & 188 & 818 \\
\hline Vocational & 110 & 50 & 107 & 267 \\
\hline
\end{tabular}


For the study sample of students, the criterion for selecting the students from the twelfth grade is that this is the last grade in the twelfth-grade classrooms. Students in this class are expected to have acquired LLS, which is the result of 12 years of learning. Besides, they are the ones who can assess to what extent they have acquired these skills.

The distribution and collection of the questionnaires took about two months in the second semester of the academic year 2018/2019.

\subsection{Study Tools}

To achieve the purpose of the study, two questionnaires were built based on the theoretical literature and previous studies in the subject to collect data from the two study samples as follows:

1) The first questionnaire was directed to the teachers to measure "the practices of the functions of the VM by school principals". It includes 40 items distributed over five areas: Transparency and management by facts, discipline at work, facilitating work and simplification and continuous improvement, on-the-job training, unification and the creation of joint ownership.

2) The second questionnaire was directed to the students to measure "the students' acquisition of the LLS". It includes 46 items distributed over three areas: Basic skills, personal and social skills, organizational skills.

\subsubsection{Validity and Reliability}

The validity of the two study questionnaires was verified by presenting them to 10 referees who are experts and specialists in educational administration and school administration at Jordanian universities. Upon agreement of more than $80 \%$ of the referees, it was ensured that the two questionnaires of the study measure the objectives of this study.

Cronbach's Alpha value was used to assess the internal consistency of the two questionnaires, which was 0.92 for the first one (VM) and 0.95 for the second one (LLS). These values confirmed the high reliability of the two questionnaires.

\subsubsection{Questionnaire Correction}

The respondents' answers on the two questionnaires were obtained by using Leckert quintuple scale as follows:

1) Very low degree, 2) Low degree, 3) Medium degree, 4) High degree, 5) Very high degree.

To judge the mean level of the two scales, the following statistical equation was used:

$\frac{\text { The upper limit of the scale }(5)-\text { The lower limit of the scale }(1)}{\text { Number of levels required (3) }}=1.33$

Then the result was added to the lower limit of the scale and to the end of each Category. Thus, the mean levels become as follows: Low level: $1-2.33$, moderate level: 2.34 - 3.67, and high level: 3.68 - 5 . 


\subsection{Statistical Analysis}

The following statistics will be used to answer the study questions and test the study hypothesis:

1) Means and standard deviation will be used to answer the first and second questions.

2) Quadruple variance analysis will be used to test the first hypothesis.

3) Triple Variance Analysis will be used to test the second hypothesis.

4) The linear regression analysis will be used to test the third hypothesis.

\section{Data Analysis and Discussion}

Q1: To what extent do the principals of Jordanian public schools practice the functions of VM from the teachers' point of view?

To answer this question, means and standard deviations were calculated as shown in Table 2.

Table 2 shows that the total mean level and the mean levels of all areas of VM are high and close, except the area of "facilitating, simplification \& improvement", which is moderate. These mean that the school principals practice the function of VM at high levels. The same table shows that the level of their practicing of the function of "on-the-job-training" is higher than the other functions, followed by "Unification \& creation of joint ownership, Discipline at work, Transparency \& management by facts", and "Facilitating, simplification \& improvement".

\section{Discussion:}

Table 2 shows that the practicing of most functions of VM by school principals is at a high level, and perhaps this result indicates that the school principals are aware of the importance of leadership because good leaders can change bad systems to better systems and strong leadership can play a major role in the success of VM. They also know that they cannot do it alone and must engage teachers and students in the VM process, which requires seeing, feeling, and understanding the processes of which they are a part. From the results in the same table, it is clear that school principals focus in a good way on transparency, Discipline at work, On-the-job-training, and Unification \& creation of joint ownership. This means that school principals and teachers are committed to achieving the goals set in the school plan and use visual mechanisms to remind themselves of what these goals are, the progress of students and class, learning goals of individual class achievement, and school progress toward goal achievement. The principals know at all times what is expected from them to lead schools in the right direction. The school principals also focus on the VM environment, which encourages interactive training, which helps them to improve their accuracy, reduce the number of obstacles in the process, and understand in a better way what is required to succeed, in addition to focusing every day on the school values because, if principals behave in a certain way, teachers and the other employees will follow. 
Table 2. Mean and standard deviation for VM.

\begin{tabular}{ccccc}
\hline VM areas & N & Mean & Std. Deviation & Mean level \\
\hline Transparency\& management by facts & 217 & 3.68 & 0.592 & high \\
Discipline at work & 217 & 3.70 & 0.690 & high \\
Facilitation, simplification \& improvement & 217 & 3.58 & 0.591 & moderate \\
On-the-job-training & 217 & 3.76 & 0.636 & high \\
Unification \& creation of joint ownership & 217 & 3.71 & 0.558 & high \\
Total & 217 & 3.71 & 0.559 & high \\
\hline
\end{tabular}

The high level of principals' practice of VM functions may be because one of the conditions for occupying the position of a school principal according to the instructions of the Ministry of Education is to hold an educational qualification in addition to his academic qualification, specifically a high diploma in school administration, or a master's or doctorate in educational administration. This means that school administrators are qualified to run schools efficiently, and they are to follow what is new in the world of administration and any updates in this area. So it may be easy for them to apply modern management concepts such as VM and try to exploit its principles and functions in upgrading the educational process to achieve the goals of the school and to raise the educational level of students and help them acquire the skills that would help them to succeed in their lives.

The same Table 2 shows that the level of principals practicing the function of Facilitating, simplification and improvement was moderate. This means that principals find some difficulties in dealing with teachers and students related to this area, which can be explained by the fact that this function relies on the way teachers and students think and behave because work can be facilitated and understood under the larger topic of human factors and work environment. Human factors are a system that investigates "behavioral, cognitive and human abilities" to understand how individuals interact. Human factors also include knowledge (how users perceive the information they receive, how this information will be processed, the nature of the resulting behavior and user decisions), behavior (acting People based on their experiences and beliefs, including factors such as school culture, personal goals, past experience), performance (speed and accuracy with which the task is completed), reliability (understanding patterns of human failure, causes of human error, and factors affecting error making).

All of the above indicate that this result may be expected because of the natural difference between individuals in their thinking, level of understanding, convictions, skills, abilities, and faith and confidence in school management and themselves, and the fact that facilitation is one of the key parts of VM.

Q2: To what extent do the students of Jordanian public schools acquire LLS from their point of view?

Means and standard deviations were calculated to answer this question as shown in Table 3. 
Table 3. Mean and standard deviation for LLS.

\begin{tabular}{ccccc}
\hline LLS areas & $\mathrm{N}$ & Mean & Std. Deviation & Mean level \\
\hline $\begin{array}{c}\text { Basic skills } \\
\text { Personal \& }\end{array}$ & 1085 & 3.71 & 0.550 & high \\
$\begin{array}{c}\text { social skills } \\
\text { Organizational skills }\end{array}$ & 1085 & 3.73 & 0.530 & high \\
Total & 1085 & 3.70 & 0.626 & high \\
& 1085 & 3.71 & 0.541 & high \\
\hline
\end{tabular}

Table 3 shows that the total mean level and the mean level of all areas of LLS are high and close. This means that the students acquire LLS at high level. Table 3 also shows that the mean of their acquiring the skill of "Personal \& social skills" is a little bit higher than the other skills, followed by "Basic skills", and "Organizational skills".

\section{Discussion:}

Table 3 shows that the school's students admitted that they possess the skills of learning at a high level, and perhaps this result indicates that, if students want to acquire LLS, they must make the effort. The ultimate goals of the learning process are always LLS and success in different educational subjects in school and after school, in the labor market and the social environment in which they live, as well as their interaction with other environments in global societies because, at the end, the student cannot reach learning for long life without achieving the process of success and the acquisition of LLS. This is consistent with the findings of the research team at the US National Education Institute that many students, especially the least competitive, need help. Those learning skills should be taught and ways should be found to implement those learning strategies (Segal \& Chipman, 1984). This result ensures that the Jordanian schools, through their programs, curricula, approach and follow-up for students, and teachers who are the most important element in schools, were able to provide students with LLS at a high level.

Teachers' awareness of the importance of the LLS that students must possess may be due to the new concepts that teachers possess in Jordanian schools. Jordan has worked to focus on the quality of education and educational outputs by moving the process of learning and teaching from the traditional form to the modern form, which puts the student at the center of attention and emphasizes the task of the teacher to help the students reach their goals, teach them what to do to reach these goals, using many modern educational strategies that focus mainly on technological and scientific development, and therefore help them to develop themselves, which requires helping them to possess the learning skills needed for it, which would lead to success now and in the future.

Students need to attach great importance to social skills to achieve success. The process of teaching and learning occurs in a social environment in the classroom and involves more than one party; in addition to the student, there is 
the teacher and there are other students. In the school environment, there are other people such as the principal, administrative and technical staff, service personnel. This environment, which includes groups of individuals, needs multiple social interactions to exchange experiences, skills and benefits between them; without these interactions, the process of students gaining experience in different situations while learning is reduced. So the student's social skills, which help him to communicate, debate, dialogue, negotiate, question, and exchange opinion may be very important for success in the acquisition of the LLS. Without it, he will remain isolated and may not be able to gain experience from the environment in which learning takes place. This explains the student's point of view, which means that they are adequately aware of the importance of the environment in which learning takes place and the importance of integrating into the learning process through direct interaction and communication with others. This can ultimately help them to benefit from these interactions in developing social skills that may contribute to their success in acquiring LLS in general. It is well-known that the learning process does not occur in a vacuum; for this process to succeed, it is necessary to combine the efforts of the school with the efforts of the home by focusing and trying to get rid of obstacles that impede the learning process, whether these obstacles are at home or school.

$H 1$ : There are statistically significant differences in practicing the functions of $V M$ by Jordanian public school principals according to education directorate, school gender, qualification, and years of experience of the teacher sample.

Means and standard deviations of VM according to the moderating variables (Table 4) and quadruple variance analysis (Table 5) were calculated to test this hypothesis.

Table 4 shows that all mean levels of all moderating variables and their levels were high, except the directorate variable, whose mean level came moderately to high. The same table also shows that the highest mean on the scale of VM, according to the directorate variable, was for "Beny Kenana", and for the school gender variable, it was for "male", while for the qualification variable, it was for "higher than bachelor", and for the experience variable, it was for "10 years or less".

The results of the quadrilateral variance analysis in Table 5 show that there is no difference in the mean scores of the sample on the VM scale due to the school gender, qualification, and experience variables, which means that teachers' view of principals' practice of VM related to these variables is very close. The same table showed that there is a difference in the mean scores of the sample on the VM scale due to the directorate variable. To find out the significance of these differences and whether they are real, one of the post-comparative tests was used (Scheffe test) (Table 6).

Scheffe test (Table 6) showed significant differences between the means of Beny Kenana and the Jordan Valley and no significant differences between the other levels of the directorate variable. 
Table 4. Mean and standard deviation for VM according to moderating variables.

\begin{tabular}{cccccc}
\hline $\begin{array}{c}\text { Moderating } \\
\text { variables }\end{array}$ & $\begin{array}{c}\text { Level of moderating } \\
\text { variables }\end{array}$ & NO. & Means & Std. Deviation & Means level \\
\hline Directorates & Beny Kenana & 99 & 3.79 & 0.527 & high \\
& Beny Obaid & 64 & 3.76 & 0.544 & high \\
& Jordan Valley & 54 & 3.52 & 0.597 & moderate \\
School gender & Male & 96 & 3.74 & 0.553 & high \\
& Female & 121 & 3.69 & 0.564 & high \\
Qualification & Bachelor or less & 186 & 3.70 & 0.562 & high \\
& Higher than bachelor & 31 & 3.77 & 0.541 & high \\
Experience & 10 years or less & 97 & 3.75 & 0.597 & high \\
& More than 10 years & 120 & 3.68 & 0.526 & high \\
VM (Total) & & 217 & 3.71 & 0.559 & high \\
\hline
\end{tabular}

Table 5. Quadruple variance analysis/Dependent variable: (VM).

\begin{tabular}{cccccc}
\hline Source & Sum of Squares & df & Mean Square & F & Sig \\
\hline Directorates & 2.449 & 2 & 1.224 & 4.008 & $0.020^{*}$ \\
School gender & 0.129 & 1 & 0.129 & 0.423 & 0.516 \\
Qualification & 0.002 & 1 & 0.002 & 0.006 & 0.940 \\
Experience & 0.161 & 1 & 161 & 0.526 & 0469 \\
Error & 64.457 & 211 & 0.305 & & \\
Corrected (total) & 67.404 & 216 & & & \\
\hline
\end{tabular}

${ }^{\star} P \leq 0.05$.

Table 6. Post-hoc tests/multiple comparisons scheffe test/dependent variable: (VM).

\begin{tabular}{ccccccc}
\hline (I) Directorate & $(\mathrm{J})$ Directorate & $\begin{array}{c}\text { Mean Differences } \\
(\mathrm{I}-\mathrm{J})\end{array}$ & Std. Error & Sig & \multicolumn{2}{c}{$\begin{array}{c}\text { 95\% Confidence } \\
\text { Interval }\end{array}$} \\
\hline \multirow{2}{*}{ Beny Kenana } & Beny Obaid & 0.02 & & & $\begin{array}{c}\text { Lower } \\
\text { Bound }\end{array}$ & $\begin{array}{c}\text { Upper } \\
\text { Bound }\end{array}$ \\
& Jordan Valley & $0.26^{*}$ & 0.093 & $0.019^{*}$ & 0.03 & 0.49 \\
Beny Obaid & Jordan Valley & 0.24 & 0.102 & 0.059 & -0.01 & 0.49 \\
\hline
\end{tabular}

${ }^{\star} P \leq 0.05$.

\section{Discussion:}

The explanation for this result in Tables 4-6, which indicates that there are no significant differences in the teachers' view of the principals' practice of the functions of VM according to school gender, qualification, and experience, is that this practice matters to all individuals in the school: teachers, students, or other employees. Therefore, the way the principal manages his school and the practice of VM functions as an administrative approach will be the same for all, especially teachers, as they are the intermediary between the administration and the students, regardless of the school gender to which they belong, or the quali- 
fications of the teachers in these schools, or the difference in their years of educational experience. These are the basics of VM that the principal stands at an equal distance from everyone, is open with them in all matters of the school, facilitates the tasks and runs the school in partnership with them; she also ensures their continuous training in accordance with their needs, abilities and expertise. In summary, VM is an invitation to work in a team that includes everyone and addresses problems and mistakes with transparency and clarity and immediately. This may justify the lack of differences in the views of teachers attributed to these variables.

On the other hand, the results of Scheffe test in Table 6 show the differences between the levels of the directorate variable, which showed statically significant differences between Beny Kenana and the Jordan Valley, where the mean of Beny Kenana is higher than that of the Jordan Valley (Table 4), and there are no differences between the other levels of the same variable.

Perhaps the differences in the teachers' points of view between the two areas are related to the general nature of these areas. Bani Kenana is a green area characterized by beautiful weather in all seasons of the year and is one of the civilized areas in Jordan, in terms of the proportion of educated people living in it, especially holders of higher education, lifestyle, services and infrastructure available, which is not different from what obtains in any civilized city in Jordan, and its population works in different professions rather than their main dependence on agriculture. Beny Kenana is very close to the center of Irbid, Jordan's second most populous city after Amman. The Jordan Valley, although a green area that relies mainly on agriculture and exports vegetables and fruits into and out of Jordan, suffers from great poverty because most of the population works in agriculture but do not own the land. In addition to the weather factor, it is a very hot area in the summer, where temperatures reach more than 40 degrees. It suffers from a lack of adequate services and infrastructure to suit weather conditions. The proportion of learners is lower than in other areas due to living conditions. The difficult conditions experienced by the Jordan Valley area may have been reflected in the level of principals exercising the functions of VM. The living and environmental conditions are undoubtedly an influential factor in the schools, which are part of this environment.

H2: There are statistically significant differences in the acquisition of LLS by Jordanian public school students according to education directorate, school gender, and the secondary education branch of the student sample.

To test this hypothesis, means and standard deviations of LLS according to the moderating variables (Table 4) and triple variance analysis (Table 5) were calculated.

Table 7 shows that all mean levels of the directorate variable were high, while the mean levels of the school gender and branch variables came moderately to high. The same table also shows that the highest mean on the scale of LLS, according to the directorate variable, was for "Beny Kenana"; for the school gender variable, it was for "male", while for the branch variable, it was for "Academic". 
Table 7. Means and standard deviation for LLS according to moderating variables.

\begin{tabular}{|c|c|c|c|c|c|}
\hline Moderating variables & Level of moderating variables & NO. & Means & Std. deviation & Means level \\
\hline \multirow[t]{3}{*}{ Directorates } & Beny Kenana & 495 & 3.72 & 0.548 & high \\
\hline & Beny Obaid & 295 & 3.70 & 0.535 & high \\
\hline & Jordan Valley & 295 & 3.71 & 0538 & high \\
\hline \multirow[t]{2}{*}{ School gender } & Male & 549 & 3.75 & 0.507 & high \\
\hline & Female & 536 & 3.67 & 0.572 & moderate \\
\hline \multirow[t]{2}{*}{ Branch } & Academic & 818 & 3.74 & 0.514 & high \\
\hline & Vocational & 267 & 3.62 & 0.610 & moderate \\
\hline LLS (Total) & & 1085 & 3.71 & 0.541 & high \\
\hline
\end{tabular}

The results of the triple variance analysis in Table 8 showed that there is no difference in the mean scores of the sample on the LLS scale due to the directorate, which means that the view of students of LLS related to this variable is very close. The same table shows that there is a difference in the mean scores of the sample on the LLS scale due to the school gender and branch variables. To find out the significance of these differences, it was returned to the table of means (Table 7), which shows that the difference is due to the schools of males where the mean is high, while the mean of female students is moderate and due to the academic branch where the mean is high, while the mean of the vocational branch is moderate. This means that male students and the students of the academic branch believe that school has a big role in enabling students to acquire those LLS more than female and vocational branches do.

\section{Discussion:}

The explanation for this result is that LLS matters to all students everywhere. Therefore, students' view of the skills necessary for success in life will not differ according to the difference in education directorate. This is because all education directorates are affiliated to the Jordanian Ministry of Education and thus follow the same regulations and instructions and receive the same material support, as well as the continuous development of administration and teachers, and the same interest in the need to follow modern education strategies, regardless of the location of the school. Sometimes, perhaps there are differences in the extent of seriousness and interest from one school to another or one teacher to another, or even from one student to another in his eagerness to acquire skills that help him in the future to succeed in his career, social and personal. This result proved that these differences are very few and did not affect the opinion of the study sample in the three educational directorates, as their views agreed that the acquisition of LLS in its three areas came high.

As for the school branch variable, the results of the variance analysis showed that there are statistically significant differences between the academic and vocational branches, where the means of academic branch is higher than that of the vocational (Table 7). 
Table 8. Triple variance analysis/Dependent variable (LLS).

\begin{tabular}{cccccc}
\hline Source & Sum of Squares & df & Mean Square & F & Sig \\
\hline Directorates & 0.038 & 2 & 0.019 & 0.065 & 0.937 \\
School gender & 1.610 & 1 & 1.610 & 5.551 & $0.019^{*}$ \\
Branch & 2.596 & 1 & 2.596 & 8.953 & $0.003^{\star}$ \\
Error & 313.201 & 1080 & 0.290 & & \\
Corrected (total) & 317.706 & 1084 & & & \\
\hline
\end{tabular}

${ }^{*} P \leq 0.05$.

This difference exists in the viewpoint for the educational branch variable, and most of the schools include the two programs, which mean the same administration, educational policies, attention, and instructions; however, the main reason may be due to differences in students' previous academic achievement. The division of students according to the instructions of the Ministry of Education between the two branches is based on their achievement in the eighth, ninth and tenth grade so that those with the highest scores go to the academic branch and the lowest to the vocational branch, and may be because these skills relate to the classroom environment and social interactions, and the nature of the subject that students are learning. The class environment and social interactions that take place within vocational classroom environments and the relationship between the teacher and students or students themselves are not the same in essence and nature with those in academic classrooms. So the students' views of the two branches are not close and express a different level of LLS.

As for the school gender variable, the results of the variance analysis showed that there are statistically significant differences between male and female schools, where the means of male for LLS is higher than that of females (Table 7). Maybe the result came in this way because of how society views of the boy and the girl, the discrimination between them in education and work and opportunities, and the preference of the boy over the girl in different areas of life. Although the situation has changed significantly from what it was, given that education in Jordan became compulsory until the tenth grade for males and females, and despite the attempts of parents, educational institutions, civil society and other institutions concerned with women's affairs and rights to support women and give them their right to education and work, males still get the preferential treatment. This is certainly reflected in the feelings and perception of the future of women and has limited their ambition so that their quest to possess the skills that qualify them to succeed in their educational, practical and social life in the future was less than the ambition of males with similar pursuits. It should be noted that, if a woman is not working in Jordanian society, she often depends on the man and he is obliged to support her, whether she is a wife, mother or sister. This is probably another reason her ambition is different from that of men, as she is less keen on acquiring the skills that qualify her to become successful.

This finding indicates to educators that, if they want to pay attention to stu- 
dents' learning and make sure they have the necessary skills to succeed in life, it may be appropriate to look at these skills and help students to possess them.

H3: There is a statistically significant effect of practicing the functions of VM by Jordanian public school principals on the student's acquisition of LLS.

This hypothesis was tested by calculating the simple linear regression (Tables 9-11) to reach the effect of practicing VM by school principals on the student's acquisition of LLS.

Table 9 shows that the VM variable explains 92\% (R-square value) of the variance of LLS variable, while the remaining percentage refers to other unknown variables.

Regression variance was analyzed to understand if R-square value has statistical significance (Table 10), and it shows the presence of statistical significance at $p<0.000$ level regarding the source of the independent variable (VM). This result confirms that VM might be one of the most important variables that could explain the acquisition of LLS by students at Jordanian public schools. So, the effect of VM on LLS acquisition is clear.

Table 11 shows the regression coefficients of VM. It shows a positive statistical significance correlation (Beta value-0.959) between the independent variable (VM) and the dependent variable (LLS). This statistical significance correlation indicated the importance of VM on the acquisition of LLS by students. This might mean that if the school principals are unable to understand the importance of practicing the function of $\mathrm{VM}$, and if there is no proper environment within the schools to help this understanding, the acquisition of LLS by students will not be achieved. It is also shown that the strength of correlation (Beta value) between VM and LLS is very high.

Table 9. Model summary.

\begin{tabular}{ccccc}
\hline Model & R & R Square & Adjusted R Square & Std. Error of the Estimate \\
\hline 1 & 0.959 (a) & 0.920 & 0.920 & 0.161 \\
\hline
\end{tabular}

a. Predictors: (Constant), VM (All).

Table 10. ANOVA (b).

\begin{tabular}{ccccccc}
\hline Model & & Sum of Squares & df & Mean Square & F & Sig \\
\hline 1 & Regression & 64.241 & 1 & 64.241 & 2485.615 & $0.000^{*}(\mathrm{a})$ \\
& Residual & 5.557 & 215 & 0.026 & & \\
\hline
\end{tabular}

a. Predictors: (Constant), VM (All), b. Dependent Variable: LLS, ${ }^{*} P \leq 0.01$.

Table 11. Coefficient (a).

\begin{tabular}{|c|c|c|c|c|c|c|}
\hline \multirow[t]{2}{*}{ Model } & & \multicolumn{2}{|c|}{$\begin{array}{l}\text { Un standardized } \\
\text { Coefficients }\end{array}$} & \multirow{2}{*}{$\begin{array}{c}\begin{array}{c}\text { Standardized } \\
\text { Coefficients }\end{array} \\
\text { Beta }\end{array}$} & \multirow[b]{2}{*}{$\mathrm{t}$} & \multirow[b]{2}{*}{ Sig } \\
\hline & & B & Std. Error & & & \\
\hline \multirow[t]{2}{*}{1} & Constant & 0.114 & 0.074 & & 1.544 & 0.124 \\
\hline & Visual management (total) & 0.976 & 0.020 & 0.959 & 49.865 & $0.000^{*}$ \\
\hline
\end{tabular}

a. Dependent Variable: LLS, ${ }^{\star} P \leq 0.01$. 


\section{Discussion:}

The result of testing hypothesis 3 shows clearly the significant effect of the independent variable (VM) on the dependent variable (LLS). Ninety-two percent of the change in LLS was caused by the principals' practice of VM functions, and this percentage was statistically significant. This means that the effect was real and not by chance. And this was confirmed by the regression coefficient table, which shows a high positive relationship between the two variables. This result may be because the functions of VM touch the reality that any school administration aspires to reach.

In addition, the effect of principals' practice of VM functions is expected to be reflected on all those involved in the school, mainly students and teachers since teachers are the main link between school administration and students, as they deal directly with students in the classroom and outside, by teaching students and providing them with various skills that help them to succeed in the future, whether in university education or the labor market or social life. The result, therefore, shows how proficient principals and teachers should be in playing their roles, which may be reinforced after the government approved the creation of a teachers' syndicate in 2011 after decades of claims.

The establishment of the syndicate and the enrollment of principals who are mainly teachers, as well as teachers, may have given high motivation to the principals and teachers to perform their functions optimally, as this syndicate has achieved stability and job security for them through the preservation of their rights and gains legally, as well as through the syndicate vision "pioneering syndicate, distinguished teacher, advanced education system, creative and belonging generation, and a safe and supportive environment”.

Thus, the principals and the teachers have become more confident in their own abilities and are seriously seeking to develop in their profession and to claim their rights boldly. At the time the researcher is writing this report, a strike by the teachers' syndicate has entered the ninth day to conduct the teaching process in all public schools in Jordan and to demand an additional 50\% bonus on the basic salary that has been promised by the government for several years.

The principals' and teachers' sense of stability and job security already achieved mainly by the syndicate may have increased their ambitions and desire for development and self-actualization through the work they do. This maybe has had a positive effect on Jordanian schools.

Therefore, the principals' practice of VM functions has, as the results show, greatly affected the students' acquisition of LLS, either directly through dealing with students on different issues or indirectly through the teacher, who is an essential element in the educational process and is undoubtedly influenced by the managerial style of the principal, which is either a driving factor in achieving the objectives of learning and teaching, the most important of which is students' acquisition of LLS, or not.

\section{Recommendations and Suggestions}

Based on the study's findings, these recommendations have been developed and 
need to be followed by policy-makers to facilitate better adoption of VM in the Jordanian education system, which would have a great positive impact on students' learning skills:

- The researcher recommends that the school's principals should pay attention to their work to facilitate simplify and develop it more than it is, because results showed that the mean level of the area of "facilitating, simplification \& improvement", is moderate.

- The researcher also recommends that more attention should be paid by all those involved in student learning, like teachers and principals, to maintain the level of students' acquisition of LLS and enable them to reach higher levels.

- The researcher also recommends that schools principals in the Jordan Valley should make greater efforts to improve their practice of VM functions, because the results of Scheffe test showed statically significant differences between Beny Kenana directorate and the Jordan Valley directorate, where the mean of Beny Kenana is higher than that of the Jordan Valley.

- The researcher also recommends that school principals and teachers should focus better on female schools and vocational schools to raise their level of LLS acquisition. Because the triple variance analysis showed that there is a difference in the mean scores of the sample on the LLS scale due to the school gender, which showed that the difference is due to the schools of males where the mean is high, while the mean of female students is moderate. And for school branch, the result showed that the mean of academic branch is high, while the mean of the vocational branch is moderate.

- She also suggests that similar studies be carried out in other schools inside and outside Jordan to identify the status of adopting VM in these schools. It is important to draw education plans as well as policies that would help establish and incorporate VM at every school in Jordan.

\section{Conclusion}

The diffusion of VM in Jordanian educational management and its impact on students' acquisition of LLS have not been widely studied in the world of academia. Identifying the teacher's attitudes towards VM can be taken as quite helpful in understanding the effect of VM on students' acquisition of LLS. The current study's findings have shown that the defusing of practicing the functions of VM in Jordanian schools is in process, and this diffusion would lead to acquiring LLS by students. And positive attitude is held by school management in their routine work. There is still a lot to do with regard to the use of VM in Jordanian educational system since it has emerged to be quite an effective mechanism for national development; while on the other hand, new development, as well as capacity building, is necessitated by it in terms of human resources. Furthermore, the current research's purpose was to inquire into the relationship between different variables in this study. This study confirms that, in developing countries, 
there may have been increasing the use of VM in the educational management of many schools. It has been confirmed by the study's results that VM has affected students' acquisition of LLS, as their performance has improved. In Jordan, it is important to consider VM as an important component within the education system. A consistent and clear picture has been presented by the findings of this study towards VM in Jordanian schools against the attitude of traditional management.

\section{Note}

This work has been carried out during sabbatical leave granted to Prof. Dalal Mohamed Al-Zoubi from Al-Balqa' Applied University (BAU) during the academic year 2018/2019.

\section{Conflicts of Interest}

The author declares no conflicts of interest regarding the publication of this paper.

\section{References}

Administrative Transparency and How to Achieve It (2017). https://www.almrsal.com/post/554821

Al-Abady, H. F. (2007). The Role of Visual Management Strategies in the Success of the Work of University Administration to Achieve Outstanding Performance. Management Studies, 1, 84-117.

Albirini, A. (2006). An Exploration of the Factors Associated with the Attitudes of High School EFL Teachers in Syria toward Information and Communication Technology. Unpublished Doctoral Dissertation, Columbus, OH: Ohio State University.

Alfalit, J. K. (2015). Self-Learning Skills Required for Graduate Students in Palestinian Universities in Gaza in the Light of the Requirements of the Knowledge Society. $\mathrm{He}$ bron University Journal for Research, 10, 28-48.

Al-Hudhali, W. B. M. (2015). The Possibility of Applying the (VM) in the (EO) in Makkah's Region and Its Relationship with Motivation of Workers. Unpublished Master Thesis, Saudi Arabia: Education College, Um al-Qura University.

Al-Tarawneh, R., \& Altweiss, A. (2018). The Effect of Using the VAK Model and Web Quest Strategy on Developing Writing Skills in the English Language of Tenth Graders in Jordanian Schools. International Interdisciplinary Journal of Education, 7, 142-150. https://doi.org/10.36752/1764-007-004-009

Bititci, U., Cocca, P., \& Ates, A. (2016). Impact of Visual Performance Management Systems on the Performance Management Practices of Organizations. International Journal of Production Research, 54, 1571-1593. https://doi.org/10.36752/1764-007-004-009

Bonds, B. G. (2003). School-to-Work Experiences: Curriculums as a Bridge. American Annals of the Deaf, 148, 38-49. https://doi.org/10.1353/aad.2003.0001

Clark, I. (2015). Formative Assessment: Translating High-Level Curriculum Principles into Classroom Practice. The Curriculum Journal, 26, 91-114. https://doi.org/10.1080/09585176.2014.990911

Gedvilienė, G., Teresevičienè, M., Zydžiūnaitė, V., \& Kaminskienė, L. (2012). Develop- 
ment of Generic Skills in Self-Learning Process in Higher Education School. Applied Research in Health and Social Sciences: Interface and Interaction, 1, 17-28.

Ghabayin, O. (2001). Self-Learning through Educational Bags. Amman: Al-Masirah Publishing \& Distribution House.

Hasan, M. (2017). How Your Employees Are Accustomed to Discipline at Work. https://www.ts3a.com/?p=36521

Hosseini, N. (2006). Lifelong Learning and the Knowledge Society: Challenges for Developing Countries. Journal of College Teaching \& Learning, 3, 1-6. https://doi.org/10.19030/tlc.v3i12.1652

Imai, M. (2018). Gemba Kaizen (2nd ed., pp. 419-426). Skillsoft.

In-Service Training (2014). Educaosy. http://educapsy.com/services/stagecours-emploi-142

Khalil, S. (2005). Humanization of Education within the Framework of Education Systems in the Arab World. http://www.ahewar.org/debat/show.art.asp?aid=34917\&r=0

Klein, B. (2017). What Facilitation Really Means and Why It's Key to the Future of Work. https://www.fastcompany.com/40467377/what-facilitation-really-means-and-why-its-k ey-to-the-future-of-work

Koichi, M., \& Hiroshi, K. (2016). Performance Evaluation of a Visual Management System for Effective Case Transfer. International Journal of Production Research, 54, 2907-2921. https://doi.org/10.1080/00207543.2015.1125542

Kurdi, A. S. (n.d.). Visual Management. Encyclopedia of Islam and Development.

Liff, S., \& Posey, P. A. (2004). Seeing Is Believing. New York: Amacom.

Ministry of Education, Jordan (2007). The National Report on Adult Education in Jordan. Risalat Almualim. Amman, Jordan.

Napolitano, A. (2017). How to Create a Sense of Ownership on Your Team without Employee Stock options.

https://www.recruiter.com/i/how-to-create-a-sense-of-ownership-on-your-team-witho ut-employee-stock-o

National Center for Assessment in Higher Education (n.d.). Professional Standards for School Principals. Kingdom of Saudi Arabia.

Segal, J. W., \& Chipman, S. F. (1984). Thinking and Learning Skills: The Contributions of NIE. Educational, Leadership, 42, 85-87.

Tezel, B. A., Koskela, L. J., \& Tzortzopoulos, P. (2009). The Functions of Visual Management. Manchester, UK: University of Salford.

Thürer, M., Stevenson, M., Silva, C., Land, M. J., Fredendall, L. D., \& Melnyk, S. A. (2014). Lean Control for Make-to-Order Companies: Integrating Customer Enquiry Management and Order Release. Production and Operations Management, 23, 463-476. https://doi.org/10.1111/poms.12058

Tjell, J., \& Bosch-Sijtsema, P. M. (2015). Visual Management in Mid-Sized Construction Design Projects. Procedia Economics and Finance, 21, 193-200. https://doi.org/10.1016/S2212-5671(15)00167-7

Waeyenbergh, G., \& Pintelon, L. (2009). CIBOCOF: A Framework for Industrial Maintenance Concept Development. International Journal of Production Economics, 121, 633-640. https://doi.org/10.1016/j.ijpe.2006.10.012

Weiler, R. (2018). Lifelong Learning: A Necessity in the Knowledge Society. E-Journal of the World Academy of Art \& Science, 2.

http://eruditio.worldacademy.org/volume-2/issue-4/article/lifelong-learning-necessity- 
knowledge-society

Witt, L. A., Kacmar, K. M., Carlson, D. S., \& Zivnuska, S. (2002). Interactive Effects of Personality and Organizational Politics on Contextual Performance. Journal of Organizational Behavior, 23, 911-926. https://doi.org/10.1002/job.172 